\title{
KOPYOR COCONUT DETECTION USING SOUND-BASED DYNAMIC TIME WARPING METHOD
}

\author{
Radon Dhelika*, Firman Ady Nugroho, Muhamad Bayu, and Alfian Kamil \\ Department of Mechanical Engineering, Faculty of Engineering, Universitas Indonesia, \\ Beji, Depok, 16424, Indonesia \\ * E-mail: radon@eng.ui.ac.id
}

\begin{abstract}
Kopyor coconut is a coconut that has genetic abnormalities which cause the coconut meat to have a unique texture and is detached from the coconut shell. Its uniqueness attracts many enthusiasts resulting in a high economic value, 4-5 times that of the ordinary coconut. From its external appearance, kopyor coconut does not differ with ordinary coconut and this poses a challenge in the detection stage. To date, both farmers and sellers use a traditional approach by listening to the sound of whisk from kopyor coconut to detect them. Unfortunately, this approach relies heavily on experience and expertise of the person. Therefore, a new detection approach is proposed based on sound recognition using Mel Frequency Cepstrum Coefficient (MFCC) as the method for feature extraction and Dynamic Time Warping $(D T W)$ as the method for feature matching. Objects that will be detected are kopyor coconuts and ordinary coconut which has grown mature. By implementing both methods, a program has been developed to detect kopyor coconut with an accuracy of $93.8 \%$.
\end{abstract}

Keywords: Kopyor Coconut, Mel Frequency Cepstral Coefficient (MFCC), Dynamic Time Warping $(D T W)$

\begin{abstract}
Abstrak
Kelapa kopyor merupakan kelapa yang mengalami kelainan genetik sehingga daging buahnya tidak menempel pada tempurung kelapa. Hal tersebut diakibatkan oleh defisiensi enzim $\alpha$-D-galaktosidase yang menyebabkan tekstur dari daging kelapa kopyor unik. Keunikan tersebut menjadikannya memiliki banyak peminat sehingga harganya lebih tinggi, mencapai 4-5 kali lipat dari harga kelapa biasa. Dari penampakan luarnya kelapa kopyor tidak berbeda dibanding kelapa biasa. Selama ini petani maupun penjual menggunakan cara tradisional dengan mendengarkan suara guncangan dari kelapa kopyor untuk membedakannya. Sayangnya, cara tersebut sangat bergantung pada pengalaman dan keterampilan dari pemilahnya. Maka dari itu, pada penelitian ini diajukan metode deteksi kelapa kopyor berbasis pengenalan suara menggunakan Mel Frequency Cepstrum Coefficient (MFCC) sebagai metode ekstraksi fitur suara dan Dynamic Time Warping (DTW) sebagai metode pencocokan fitur suara. Objek yang akan dideteksi adalah kelapa kopyor dan kelapa biasa yang sudah tua. Dengan menggunakan kedua metode tersebut, sebuah program telah dibuat untuk dapat mendeteksi kelapa kopyor dengan akurasi sebesar 93.8\%.
\end{abstract}

Kata Kunci: Kelapa Kopyor, Mel Frequency Cepstral Coefficient (MFCC), Dynamic Time Warping $(D T W)$

\section{Introduction}

Kopyor coconut is a coconut with genetic abnormalities which result in a unique texture of the meat. The meat is soft, crushed, and detached from the shell due to the lack of one of the enzymes that plays a role in the formation of the meat, i.e. enzyme $\alpha$-D-galactosidase. Because of these genetic abnormalities, kopyor coconut is relatively rarer than ordinary coconut. The scarcity, combined with a large demand, have contributed to its high economic value in the market [1].

From its external appearance, kopyor coconut does not differ much with ordinary coconut. Therefore, one notable challenge in the postharvest stage of kopyor coconut is its detection. To date, both farmers and sellers use a traditional approach by listening to the sound of the whisk from the coconut when shaken. Though this has been universally accepted, such a qualitative 
approach is found to pose several problems, such as wrong detection and huge reliance to experienced persons as the detector. A new approach that incorporates a quantitative method is expected to offer an added value to the existing one.

In the research domain of post-harvest fruit quality detection, such as for sorting, there have been abundant methods to quantify common fruit parameters such as fall test and impact force response to measure the hardness of peaches [2], and the use of reflectance from Near Infrared (NIR) to measure the internal quality of the fruit [3]. Among those methods, the ones most relevant to this study are the use of sound to measure the maturity of fruits and vegetables [4-5], such as mangoes [6], avocados [7] and tomatoes [8]. However, of all existing literature, none had specifically examined the method of detection of kopyor coconut. Additionally, most notable approaches utilize the principle of ultrasound [4-8] which are arguably costly due to the need to provide the ultrasonic generator.

Therefore, in this research, we propose a quantitative detection method based on a simple sound recognition so as to improve the accuracy and reliability of kopyor coconut detection process. To the best of our knowledge, this work is the first to attempt a sound recognition for the detection of kopyor coconut.

\section{Basic Theory}

\section{Kopyor Coconut}

Kopyor coconut is a natural mutant coconut that has abnormal development in its endosperm (the coconut meat), so the endosperm is detached from its shell. The endosperm sports a jelly-like soft texture, and some or even all of the endosperms are detached from the coconut shell and mixed with coconut water. Those characteristics describe the most distinct features of a kopyor coconut: the meat being detached from the shell and the less water content [1, 9-10].

One suspected cause of the release of endosperm from the shell on kopyor coconut is due to the deficiency of the enzyme $\alpha$-D-galactosidase, one of the enzymes needed in the formation of endosperms in coconut plants [11]. The deficiency leads to the breaking of endospermic tissue connection with the embryo, so naturally endosperm cannot support the growth of embryo [12]. Therefore, the growing of kopyor coconut is generally done by planting an ordinary coconut fruit that comes from bunches that produce kopyor fruits, in a hope that the fruit grows into a seed that introduces kopyor. These seeds are known as natural seeds.

Kopyor coconut is understood to emerge naturally and is inherited through recessive genes [12]. Kopyor will occur when the pollination of a female flower or ovary that possesses a kopyor recessive gene $(\mathrm{k})$ meets a male's flower having a recessive gene $(\mathrm{k})$ either in the same tree or in a different one.

Furthermore, it was also reported that the price of kopyor coconut can reach 4 to 5 times that of the ordinary coconut [12]. The price is justified because kopyor coconuts are very rare. Bunches derived from ordinary coconut seeds generally only produce one to two kopyor coconuts whereas bunches derived from kopyor coconut seedlings do not necessarily produce kopyor coconut entirely.

This leads to the importance of sorting out the kopyor coconut from the ordinary coconut correctly. It is generally understood that morphologically, kopyor coconut is difficult to distinguish from ordinary coconut [13]. However, by a traditional approach, i.e. shaking the fruit, the gurgling sound from the coconut water in the fruit can be used to distinguish between the two types of coconut. Currently, farmers and sellers of kopyor coconut can detect kopyor coconut by such an approach. Unfortunately, the traditional method is based on an expertise of the person doing the detection. The over reliance to an expert to perform the crucial stage in the post harvest is undesirable. Additionally, the use of the traditional approach result in detection errors which could add an undesirable production cost [14].

Kopyor coconut can be distinguished from ordinary coconut using its whisk sound when the

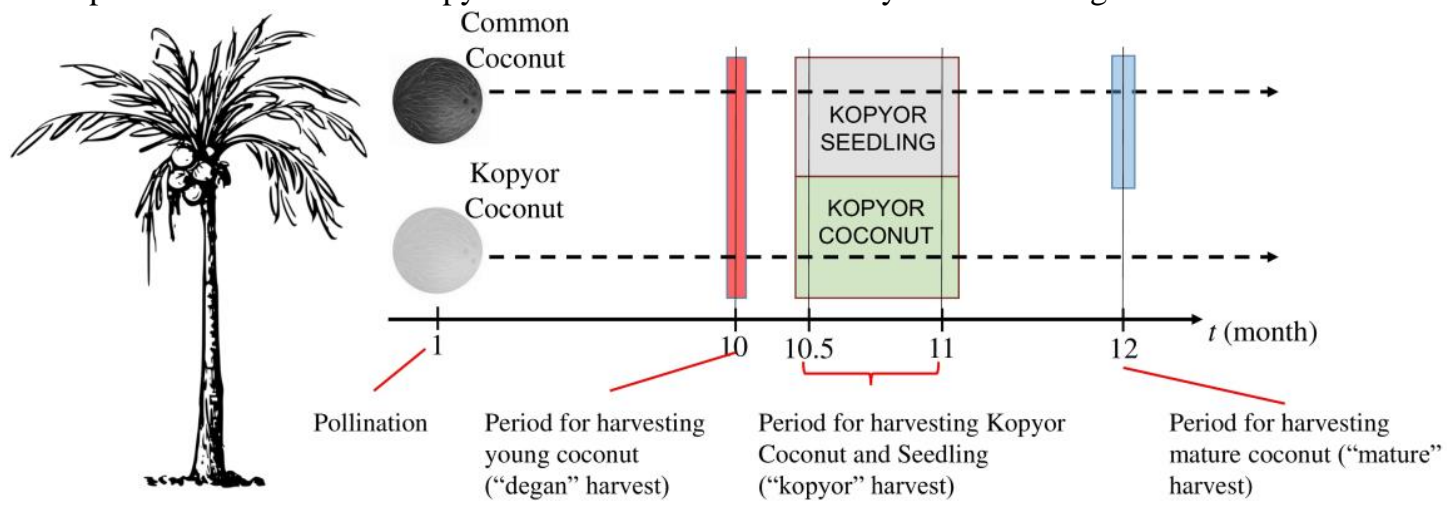

Figure 1. Timeline of kopyor coconut harvest from natural kopyor coconut tree 
coconut is older than 10 months old [15]. Therefore, the majority of coconuts to be detected are old coconut and kopyor coconut, as shown in the timeline of kopyor and ordinary coconut in Figure 1. From the figure, it can be seen that the harvest period of kopyor coconut coincides with that of ordinary coconut containing kopyor gene but not expressed (kopyor seedling) that has the same meat structure as the old coconut. Therefore, this study will only focus on the detection of kopyor coconut and old coconut.

\section{Mel Frequency Cepstral Coefficient (MFCC)}

The coefficient of MFCC is a coefficient that represents a sound based on perception and is obtained from Mel-frequency spectrum. It is well understood that the hearing system of human being is more sensitive to sounds of higher frequencies than lower frequencies. In the Mel-frequency cepstrum, the frequency band is evenly distributed over each range of frequency, thus makes it closer to the response of the human hearing system than to the linear frequency division of the normal cepstrum.

In this research, MFCC is chosen as the method for feature extraction as it is commonly used for problems involving sound, especially for speech recognition [16-19].

The sound signal can be converted to MFCC by following sequential steps: pre-emphasis, framing, windowing, Discrete Fourier Transform (DFT), Mel Frequency Transform, and finally Discrete Cosine Transform (DCT). The result of the final step is the MFCC value which is the amplitude of the resulting spectrum. The resulting coefficient can also be referred to as an acoustic vector [16].

\section{Dynamic Time Warping (DTW)}

Dynamic Time Warping (DTW) is a method used to find the resemblance of two signals by calculating the corresponding optimal distance from each point of both signals so that a point from the signal can have a relationship with more than a single data point from the other signal. DTW is chosen as the method for feature matching because it is simple yet robust to shift in time domain. It is also generally understood that the method is suitable for detection problems involving sound $[16,20,21]$. In sound recognition, DTW is commonly used to determine if two waveforms represent the same phrase. The shape of the two waves usually varies in the form of sound waves, the duration of each spoken sound, and the interval between sounds.

\section{Method}

In this study, the type of kopyor coconut used was genjah kopyor coconut whose husk has been peeled from the coconut shell. There are three groups of sound samples, namely the sound from kopyor A, kopyor B, and old coconut. Kopyor A and $\mathrm{B}$ refer to kopyor coconuts having a less and more volume of coconut water, respectively. The sound samples of each group were taken from three different coconut samples. The number of sound samples taken from each group is shown in Table 1. For each group of kopyor coconut, each coconut sample was shaken eight times to produce 24 different sound samples. As for the old coconut, each sample was shaken 16 times to produce 48 different sound samples. The reason for this difference is to maintain the balance of the total number of data in each category of coconuts (kopyor and old coconut), i.e. 48.

TABLE 1

NUMBER OF SOUND SAMPLES PER GROUP

\begin{tabular}{lcccc}
\hline & Kopyor A & Kopyor B & $\begin{array}{c}\text { Old } \\
\text { Coconut }\end{array}$ \\
\hline $\begin{array}{l}\text { Number of } \\
\text { sound samples } \\
\text { Number of } \\
\text { coconuts }\end{array}$ & 24 & 24 & 48 \\
\hline
\end{tabular}

The sound sample was taken at a location marked by the presence of three black dots on the coconut shell, as shown in Figure 2(a).

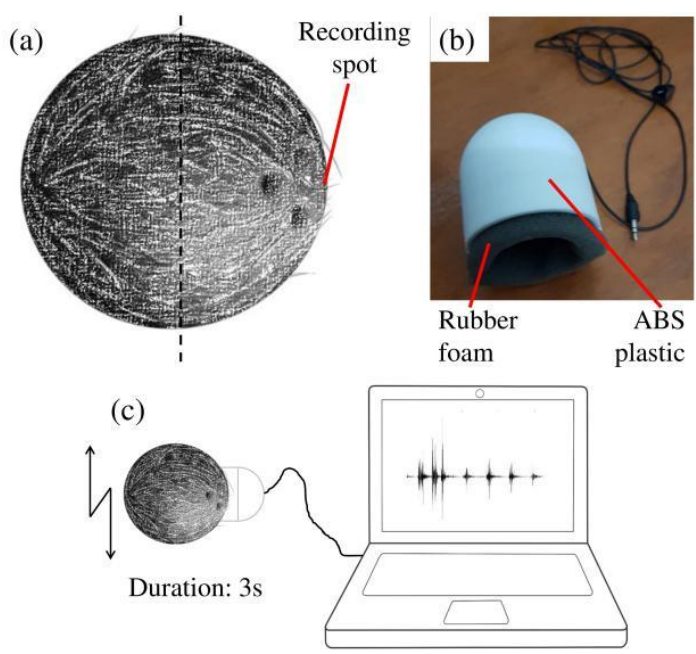

Figure 2. (a) Recording spot on coconuts, (b) Container for noise reduction, (c) Experimental setup for data taking

The sound was taken using a microphone placed on a container, whose design is shown in Figure 2(b). This was done to minimize the noise from the environment especially those coming from the friction between microphone and coconut 
shell. The whole experimental setup is shown in Figure 2(c). After the container was affixed to the coconut, the coconut was grasped with hands using latex gloves. This was to avoid the friction between the skin and coconut shell and to protect the hands from the possibility of being injured with sharp edges of the coconut. The coconut was then shaken and the sound produced was recorded for three seconds. The recorded sound was saved into the database.

Subsequently, as the training stage, all sound samples stored in the database were processed with MFCC method, with used parameters tabulated in Table 2. The result of MFCC extraction from each sample was a matrix with a size of 24 x 198.

TABLE 2

MFCC PARAMETERS USED

\begin{tabular}{lc}
\hline \multicolumn{1}{c}{ Parameter } & Value \\
\hline Frame shift & $10 \mathrm{~ms}$ \\
Frame duration & $25 \mathrm{~ms}$ \\
Pre-emphasis coefficient & 0.97 \\
No of filterbank & 18 \\
No of cepstral coefficient & 23 \\
Lower frequency & $0 \mathrm{~Hz}$ \\
Upper frequency & $685 \mathrm{~Hz}$ \\
Cepstral sine lifter & 22 \\
Sampling rate & $44100 \mathrm{~Hz}$ \\
\hline
\end{tabular}

Afterwards, as the testing stage, the features of the signal to be measured for resemblance will be compared with each database feature. Since DTW can only calculate the similarities of two rows of data, each sample that was compared to each other will undergo 24 DTW processes for each corresponding row and generate 24 equal values of each row. The value of the final similarity was obtained by averaging the 24 values. The smallest similarity of the end values indicates that the processed signal has the closest resemblance to the sample. The flow of the overall process involved from data taking until detection is given in Figure 3.

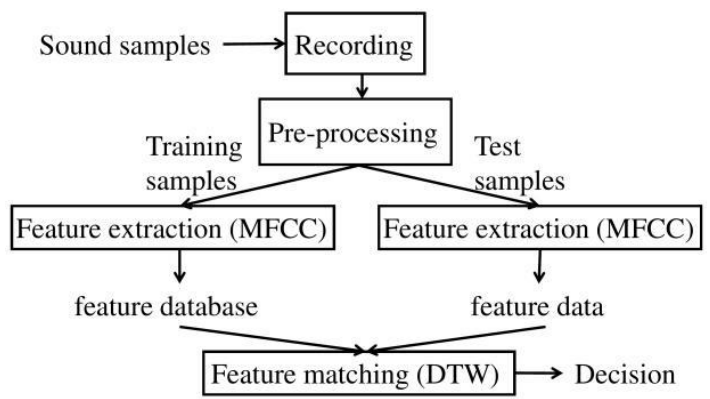

Figure 3. Flow of the overall process

\section{Results and Discussion}

After the whole process, the final data obtained is a matrix of similarity values (DTW score) with a size of $96 \times 96$. The processing time was 283 seconds. To provide a better visualization, each value was normalized by dividing it with the highest similarity value among the whole data, i.e. 1461.2. Subsequently, each cell was colored with a three-color scale of green (high value), yellow (mid value), and red (low value) and the final matrix is as shown in Figure 4.

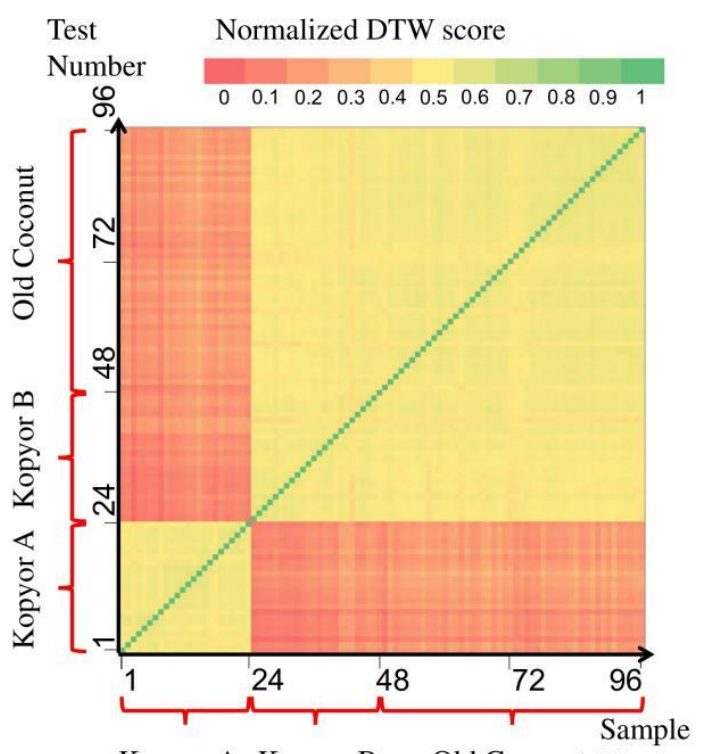

Kopyor A Kopyor B Old Coconut Number

Figure 4. Visualization of normalized DTW score which shows similarity values

The smallest value of 0 is given the red color and the largest value of 1 is given the green color. The more similar the two samples when compared, the greener the color is. If the color is exactly green, then the two samples being compared are the same sample (autocorrelation), as shown by the green diagonal line. This color scale visualizes the dispersion area of the similarity value of each sample that has been compared with 96 other samples.

From Figure 4, it can be observed that the similarity values in each of their own group (kopyor A, kopyor B, old coconut) are high, indicated by the yellowish color throughout. This means that the matching process using DTW algorithm succeeded in recognizing a sample of kopyor A as a kopyor A, and so on. Specifically for kopyor A, the system is able to discriminate successfully from other groups as well, indicated by reddish-colored area for sample number 1 to 24 .

It is worth noting, however, that though ingroup matching for kopyor B and old coconut show 
high similarity values, when the two groups (kopyor B and old coconut) are compared to each other, the resulting similarity values are difficult to distinguish; they both have the yellowish color throughout. This fact, backed up by our observation, might arguably be contributed by the alike amount of water between kopyor B and old coconut. As explained in previous section, the main difference in feature between kopyor A and B is the amount of water content; the former has less volume of coconut water than the latter. Since kopyor B has more water content, it has become closer in characteristic to that of old coconut that this plays a crucial role in the resulting DTW scores.

Furthermore, detection was also performed based on the similarity values obtained. The system was programmed to compare all similarity values among all samples and pick the highest value as the best match. The result is as tabulated in Table 3 below. The confusion table is obtained from the results of detection program executed for each sample of sound over the entire samples.

Accuracy is defined as the total number of correct detection divided by the total number of detection attempt, formulated in (1). Group accuracy is the accuracy of the program to select each sample from each group (kopyor A, kopyor B, or old coconut). Correct detection is considered if the program classifies each test sample to the appropriate group. On the other hand, category accuracy is the accuracy of the program to select each sample from each group to the category (kopyor or old coconut). Correct detection is considered if the program classifies each sample test into the appropriate category.

$$
\text { accuracy }=\frac{\sum \text { correct detection }}{\sum \text { detection attempt }}
$$

TABLE 3

CONFUSION TABLE

\begin{tabular}{lccc}
\hline & Kopyor A & Kopyor B & Old coconut \\
\hline Kopyor A & 24 & 0 & 0 \\
Kopyor B & 0 & 21 & 0 \\
$\begin{array}{l}\text { Old } \\
\text { coconut }\end{array}$ & 0 & 3 & 48 \\
$\begin{array}{l}\text { Group } \\
\text { accuracy } \\
\begin{array}{l}\text { Category } \\
\text { accuracy }\end{array}\end{array}$ & $100 \%$ & $87.5 \%$ & $100 \%$ \\
\hline
\end{tabular}

From Table 3, it can be inferred that the detection accuracy of kopyor coconut as a whole category is good, reaching $93.8 \%$. The accuracy value could be improved in the future by increasing the number of samples or finding the more suitable MFCC parameters.

\section{Conclusion}

A program for detection of kopyor coconut based on sound recognition using MFCC and DTW method has been developed with the categorical detection accuracy of $93.8 \%$. It is therefore expected that the proposed method could be developed further to aid the post-harvest detection process of kopyor coconut to have a better accuracy and reliability. Further development of this program can be carried out to measure the quality or maturity of the kopyor coconut that has been detected, and its use to develop a full-fledged device for practical use in the field.

\section{Acknowledgement}

This work was partially funded by Hibah PDUPT Kemenristekdikti fiscal year 2018 (418/UN2.R3.1/HKP05.00/2018).

Acknowledgments are also given to Dr. Imran Riyadi of Research Institute for Biotechnology and Bioindustry (PPBBI Bogor), for the provision of data during the interview and Mr. Krismayadi, the owner of Rajawali Kopyor, for the supply of kopyor coconut.

\section{References}

[1] Santoso, Umar, Kazuhiro Kubo, Toru Ota, Tadahiro Tadokoro, and Akio Maekawa. "Nutrient composition of kopyor coconuts (Cocos nucifera L.)." Food Chemistry 57, no. 2, pp. 299-304. 1996.

[2] Wang, Yong-wei, Jun Wang, Chong Yao, and Qiu-jun Lu. "Firmness measurement of peach by impact force response." Journal of Zhejiang University SCIENCE B 10, no. 12 pp. 883. 2009.

[3] Lammertyn, Jeroen, Ann Peirs, Josse De Baerdemaeker, and Bart Nicola1. "Light penetration properties of NIR radiation in fruit with respect to non-destructive quality assessment." Postharvest Biology and Technology 18, no. 2, pp. 121-132. 2000.

[4] Mizrach, A. "Ultrasonic technology for quality evaluation of fresh fruit and vegetables in pre-and postharvest processes." Postharvest biology and technology 48, no. 3, pp. 315-330. 2008.

[5] Awad, T. S., Moharram, H. A., Shaltout, O. E., Asker, D., \& Youssef, M. M. (2012). Applications of ultrasound in analysis, processing and quality control of food: A review. Food research international, 48(2), 
410-427.

[6] Mizrach, A., U. Flitsanov, and Y. Fuchs. "AN ULTRASONIC NONDESTRUCTIVE METHOD FOR MEASURING MATURITY OF MANGO FRUI." Transactions of the ASAE 40, no. 4, pp. 1107-1111. 1997.

[7] Mizrach, Amos. "Determination of avocado and mango fruit properties by ultrasonic technique." Ultrasonics 38 , no. 1-8, pp. 717722. 2000.

[8] Mizrach, Amos. "Nondestructive ultrasonic monitoring of tomato quality during shelf-life storage." Postharvest Biology and Technology 46, no. 3, pp. 271-274. 2007.

[9] Prasetyo, H. \& Rahmat, A., "Pengembangan teknik penyelamatan embrio kelapa kopyor (Cocos nucifera L.) secara in-vitro". Skripsi. Jawa Timur, Universitas Pembangunan Nasional "Veteran", Indonesia, 2003. (in Bahasa Indonesia)

[10] Mashud, N. 2008. Teknologi kultur embrio untuk pengembangan kelapa kopyor. Warta Penelitian dan Pengembangan Tanaman Industri. 14 (2): 9 - 11. (in Bahasa Indonesia)

[11] Sukendah, S., Hugo Volkaert, and S. Sudarsono. "Isolation and Analysis of DNA Fragment of Genes Related to Kopyor Trait in Coconut Plant." Indonesian Journal of Biotechnology 14, no. 2.

[12] Maskromo, I., N. Mashud, and H. Novarianto. "Potensi pengembangan kelapa kopyor di Indonesia." Warta Penelitian dan Pengembangan Pertanian 13, no. 1, pp. 4-6. 2007.

[13] Warisno. Budidaya Kelapa Kopyor. Kanisius: Yogyakarta. 2003. (in Bahasa Indonesia)

[14] Krismayadi. 2017. Interview on 10 November 2017. Rajawali Kopyor, distributor of kopyor in Jakarta.

[15] Riyadi, I. 2018. Interview on 6 March 2018. Researcher in Indonesian Research Institute for Biotechnology and Bioindustry, Bogor.

[16] Muda, Lindasalwa, Mumtaj Begam, and Irraivan Elamvazuthi. "Voice recognition algorithms using mel frequency cepstral coefficient (MFCC) and dynamic time warping (DTW) techniques." arXiv preprint arXiv:1003.4083. 2010.

[17] Darabkh, Khalid A., Ala F. Khalifeh, Baraa A. Bathech, and Saed W. Sabah. "Efficient DTW-based speech recognition system for isolated words of Arabic language." In Proceedings of International Conference on Electrical and Computer Systems Engineering (ICECSE 2013), pp. 689-692. 2013.

[18] Saksamudre, S. K., Shrishrimal, P. P., \&
Deshmukh, R. R. (2015). A review on different approaches for speech recognition system. International Journal of Computer Applications, 115(22).

[19] Alías, F., Socoró, J. C., \& Sevillano, X. (2016). A review of physical and perceptual feature extraction techniques for speech, music and environmental sounds. Applied Sciences, 6(5), 143.

[20] Salvador, Stan, and Philip Chan. "Toward accurate dynamic time warping in linear time and space." Intelligent Data Analysis 11, no. 5, pp. 561-580. 2007.

[21] Hsu, C. J., Huang, K. S., Yang, C. B., \& Guo, Y. P. (2015, January). Flexible Dynamic Time Warping for Time Series Classification. In ICCS (pp. 2838-2842). 